\title{
Dynamics of Road Infrastructure Support of Russian Regions' Economic Subsystems
}

\author{
Anna Yu. Kosobutskaya \\ Voronezh State University \\ Voronezh, Russia \\ E-mail: anna.rodnina@mail.ru
}

\author{
Mikhail. N. Bakhtin \\ Voronezh State University \\ Voronezh, Russia \\ E-mail: bakhtinmn@yandex.ru
}

\begin{abstract}
The article is devoted to the study of road infrastructure service parameters of economic subsystems in Russian regions. The maintained subsystems are the followings: mining, manufacturing, agriculture, investment, construction, trade, value added (gross regional product), population. Taking into consideration the significant number of regions in the Russian Federation, they are arranged into relatively homogeneous groups (virtual clusters) through cluster analysis. Representative regions nearest to the center of each cluster are identified in each virtual cluster. In case of significant number of regions in one virtual cluster, secondary clustering was performed to obtain groups that are more homogeneous. The article does not provide data on regions with the lowest rate of economic subsystems service due to the high heterogeneity of the virtual clusters obtained. Donor subsystems (characterized by a high level of service parameter) and recipient subsystems with a low level of service parameter are identified in each representative region. In relation to the representative regions, a dynamic analysis was undertaken, which allowed identifying the main trends in the service intensity of economic subsystems.
\end{abstract}

Keywords—road infrastructure; virtual cluster; region; economic subsystem

\section{INTRODUCTION}

Problems of infrastructure development are constantly in the focus of attention of government authorities. Over the course of three decades, they have been reflected in various strategic planning documents at the federal, regional and local levels. Such attention requires a detailed study of not only the state of the roads as transport infrastructure elements, but also an assessment of the relationship between infrastructure level and level of regions' main economic subsystems development. M. Bitarova, K. Getmantsev, E. Ilyasova, E. Krylova, Yu. Vertakova, V. Mkrtyachan, V. Plotnikov, D. Treschevsky, N. Firsova and other researchers considered the problem [1], [2], [3].

\section{MethodologicAl ApProACH to AsSESSMENT OF ROAD INFRASTRUCTURE SUPPORT OF RUSSIAN REGIONS' ECONOMIC SUBSYSTEMS}

To assess the state and prospects of the transport infrastructure development in the regions, we clustered them according to infrastructure support of various socio- economic subsystems. The following parameters were selected for the analysis: volumes of shipped goods of mining and quarrying, manufacturing; agricultural production; fixed capital investments; volume of work performed by economic activity "Construction"; turnover of trade organizations; gross regional product; population. These indicators are referred to the roads length. The obtained specific indicators (per $1 \mathrm{~km}$ of roads) are presented in a normalized form to obtain a comparable data array. Further processing was performed through cluster analysis, the theoretical foundations of which were developed by I. Mandel, M. Oldenderfer, R. Bleshfield, I. Hartigan, and M. Wong [4], [5], [6]. Methodological aspects of cluster analysis application in the context of regional economy are presented in the works of O. Golichenko, V. Kruglyakova, T. Myasnikova, M. Litovkina, I. Risin, I. Terzi, D. Treschevsky, Yu. Treschevsky, I. Shchepina and other researchers [7], [8], [9], [10].

The time series (from 2012 to 2016 inclusive) cover various periods of the country and its regions development: 2012 - stable economic situation, 2013 - deterioration in the business environment, 2014 and 2015 - a wide range of crisis phenomena (sanctions and ruble depreciation), 2016 economic stabilization and return to relatively normal conditions.

The initial data were obtained from the official statistical sources [11], [12], [13], [14], [15], [16], [17].

\section{VIRTUAL ClUSTERS OF ROAD INFRASTRUCTURE SUPPORT OF RUSSIAN REGIONS' ECONOMIC SUBSYSTEMS}

For analysis, the regions were arranged in five clusters. The clusters are named "A", "B", "C", " $D$ ", and "E" in descending order of the total results calculated according to normalized indicators. To assess the homogeneity of clusters, the F-criterion was used; to assess the significance of the average values, the p-criterion was used. The statistical characteristics of clusters comply the requirements of homogeneity and significance. The characteristics of the virtual clusters obtained are the followings.

Cluster " $A$ " is the most developed in terms of the economic subsystems' infrastructure support of the regions. The infrastructure support of construction and mining has the 
natural factors). In relation to construction, the changes are precipitous; growth is relative to the initial period. As in the case of manufacturing, there is a loosely correlation between the indicator values in the dynamic series. The low level of correlation and determination coefficients is largely due to the increase in the length of roads in 2013 (from 22,022.7 km in 2012 to $29,362 \mathrm{~km}$ in 2013). The state of the supported subsystems changed slightly.

In the representative region of cluster "C" - the Samara Region, the rate of the infrastructure support of manufacturing decreased markedly. The reduction was particularly expressed in 2013, but, although less noticeable, it continued in subsequent years. At the same time, volumes of shipped goods of manufacturing (respectively, by years: 757,$031 ; 780,879 ; 833,357 ; 928,775 ; 938,869$ million rubles) and the length of roads (respectively, 22,099.7; 27,289.8; $31,153.7 ; 31,330.9 ; 36,673.7 \mathrm{~km})$ increased.

Rate of infrastructure support of agriculture is volatile.

Strong decrease in the rate of infrastructure support of the recipient subsystems (created value, investment) is observed. It changed unevenly, and the coefficients of correlation and determination are low.

Thus, we can assume that only a decrease of infrastructure support of manufacturing can be established reliably (although at the maximum level of the coefficient of determination).

We will proceed to an analysis of the rate of infrastructure support of the economic subsystems in the Krasnodar Krai (the region is the representative of the "D1" sub-cluster). In general, the length of roads in the Krasnodar Territory is growing steadily with an average growth rate of 2.4 per cent per year. Therefore, relative ratios vary depending more on trends absolute indicators for supported economic subsystems.

In general, it is possible to establish with a high confidence the positive dynamics of the infrastructure support of mining (correlation coefficient of the linear equation is 0.765 ).

The rate of infrastructural support of investments in fixed assets shows a negative trend. In 2013, the indicator assumed the maximum value (25.05 million rubles / $\mathrm{km})$. In subsequent years, it steadily decreased. Over the analyzed period, the indicator value fell by more than half (in 2016 it amounted to 10.5 million rubles / $\mathrm{km}$ ). The correlation coefficient is very high (0.8). However, amount of investments in the "G1" cluster representative region is huge by the standards of the Russian regions (respectively, by years: 798,476; 955,208; 750,236; 586,903; 428,972 billion rubles), which does not allow us to consider it typical for this indicator. Such kind of divergence is possible in other regions. Therefore, we consider it necessary to identify a group of regions "atypical" phenomena related in this case to investment processes. Relating to the Krasnodar Territory, the reason for this is simple - at the start of the researched period intensive construction of facilities for the Winter Olympic Games was going on. However, similar processes may relate to other economic phenomena. 
rate of infrastructure support of fix capital investments with regard to the length of roads. The amount of fix capital investments declined 9 per cent in general over the period, while the length of the roads increased slightly (by 0.3 per cent). The determination coefficient is low (below 0.3).

The volume of construction over the period 2012-2013 decreased by 3.5 per cent, while the length of the roads practically did not increase. Accordingly, the rate of infrastructure support increased. In general, the dynamics of the infrastructure support of construction is described by a positive linear trend with sufficiently high coefficients of correlation and determination.

The turnover of trade organizations in the period from 2012 to 2013 decreased by 1.5 per cent, while the length of the roads remained unchanged. The rate of infrastructure support of wholesales increased thereafter with a slowing growth rate in 2015-2016. In general, the dynamics is described by a linear trend with a sufficient coefficient of determination.

The ratio of GRP to the length of roads for the entire analyzed period increased by 39.5 per cent, the GRP increased from 2012 to 2016 almost by 40 per cent. On average, the region's GRP increased by 8.7 per cent annually. Accordingly, the dynamics of the infrastructure support of GRP is described by a linear trend with an extremely high level of determination (about 1.0).

The population of the Adygea Republic has little dynamic potential. In general, during the analyzed period, the increase rate was 2 per cent. The length of the roads in the region increased by only 0.3 per cent for the period from 2012 to 2016. Such minor changes in absolute indicators led to a low increase in the rate of infrastructure support (by 1.7 per cent). According to this indicator, the situation in the republic is quite stable; the trend is described by a linear dependence with a high coefficient of determination.

\section{CONCLUSION}

A generalization of the above allows us to draw the following conclusions.

The representative regions of the virtual clusters, leading in terms of the rate of infrastructure support of economic subsystems of the regions - Sverdlovsk and Samara regions show a decrease in the corresponding indicators. In most instances, the dynamics is described by regression equations with sufficient confidence. There are also trends characterized by significant fluctuations. This is especially true of agricultural production, the results of which are most dependent on natural phenomena.

Three significantly different groups represent regions with an average level of development (cluster " $D$ "). The Krasnodar Territory represents the "D1" sub-cluster. Extremely high activity for the Russian regions in road construction, investments and construction in the early 2010s subsequently reduced a rate of infrastructure support of investments and construction subsystems.

The Adygea Republic represents the "D3" sub-cluster. In the timeframe 2013-2016, the region shows a decrease in the 
seminar / ed. K.V. Getmantseva, T.A. Myasnikova. Krasnodar: KubSU, 2018. Pp. 116-119.

[11] Regions of Russia. Socio-economic indicators. 2011: Statistical book. / Rosstat. Moscow, 2011. - 990 p

[12] Regions of Russia. Socio-economic indicators. 2012: Statistical book. / Rosstat. Moscow, 2012. - 990 p.

[13] Regions of Russia. Socio-economic indicators. 2013: Statistical book. / Rosstat. Moscow, 2013. - 990 p.

[14] Regions of Russia. Socio-economic indicators. 2014: Statistical book. / Rosstat. Moscow, 2014. - 900 p.

[15] Regions of Russia. Socio-economic indicators. 2015: Statistical book. / Rosstat. Moscow, 2015. - 1266 p.

[16] Regions of Russia. Socio-economic indicators. 2016: Statistical book. / Rosstat. Moscow, 2016. - 1326 p.

[17] Regions of Russia. Socio-economic indicators. 2017: Statistical book. / Rosstat. Moscow, 2017. - 1402 p.

\section{REFERENCES}

[1] Bitarova M.A., Getmantsev K.V., Ilyasova E.V., Krylova E.M., Treshchevsky Yu.I. Factors of Socio-Economic Development of Rural Regions in the Area of Influence of City Agglomerations // The Future of the Global Financial System: Downfall or Harmony: Part of the Lecture Notes in Networks and Systems book series (LNNS). Vol. 57. Springer. Nature Switzerland AG 2019. Switzerland. 2018. Pp. 183-194.

[2] Mkrttchian V., Vertakova Y., Treshevski Y., Firsova N., Plotnikov V., Treshchevsky D. "Smart City" - the concept of resolving the contradiction between production and urban life. In: Benna U.G. (ed.) Industrial and Urban Growth Policies at the Sub-National, National, and Global Levels. Hershey, PA: IGI Global. 2018. Chapter 15. - 363 p.

[3] Yuri I. Treshchevsky, Valeri P. Voronin, Maria B. Tabachnikova, and Galina N. Franovskaya. Economic and Statistical Analysis in Evaluating the Perspectives of Structural Changes of Regions' Economy // Advances in Intelligent Systems and Computing. Springer International Publishing AG; Cham, Switzerland. 2018. Pp. 521-529.

[4] Mandel I.D. Cluster analysis. Moscow, Finance and statistics. 1988. $176 \mathrm{p}$.

[5] Oldenderfer M.S. Cluster analysis // Factor, discriminant and cluster analysis / M.S. Aldenderfer, R.K. Bleshfield. Ed. I.S. Enyukova. - M.: Finance and Statistics, 1989. - 215 p.

[6] Hartigan I.A. Algorithm AS 136: A K-Means Clustering Algorithm / J.A. Hartigan, M.A. Wong // Journal of the Royal Statistical Society Series C (Applied Statistics). 1979. Vol. 28, N 1. Pp. 100-108.

[7] Yuri Treshchevsky, Larisa Nikitina, Mikhail Litovkin, Valentina Mayorova. Results of innovational activities of Russian Regions in view of the types of economic culture // Russia and the European Union Development and Perspectives Part of the series Contributions to Economics. Book. Contributions to Economics, 2017. Pp. 47-53.

[8] Anna Yu. Kosobutskaya, Mikhail N. Bakhtin. Trends of SocioEconomic Development in the Russian Regional Space. Growth Poles of the Global Economy: Emergence, Changes and Future Perspectives. Springer. 2020. Pp. 1121-1129.

[9] Treschevsky D.Yu. The cluster approach to the analysis of innovative development of Russian regions // Region: systems, economics, and management. 2011. No1 (12). Pp. 37-47.

[10] Kosobutskaya A. Yu., Bakhtin M.N., Papin S.N., Penina E.O. Functional localization of road infrastructure in the regional economic space of the country. Regional economic strategy: issues of choosing technology for practical implementation: materials of a scientific 